\title{
International Permafrost Association
}

\author{
http://www.geo.uio.no/IPA/
}

\section{History and Objectives}

The International Permafrost Association, founded in 1983, has as its objectives to foster the dissemination of knowledge concerning permafrost and to promote cooperation among persons and national and international organisations engaged in scientific investigation and engineering work related to permafrost and seasonally frozen ground. The IPA became an Affiliated Organisation of the International Union of Geological Sciences (IUGS) in July 1989.

Permafrost or perennially frozen ground is defined as earth material that remains at or below $0^{\circ} \mathrm{C}$ for at least two consecutive years. As such upwards of $25 \%$ of Planet Earth is underlain to some degree by permafrost and in extreme conditions reaches depths of 1500 meters. Permafrost occurs in the high latitudes and mountains and plateaus of both hemispheres. Its spatial distribution is illustrated in Figure 1.

The Association's primary responsibilities are to convene International Permafrost Conferences, undertake special projects such as preparing databases, maps, bibliographies, and glossaries, and coordinate international field programmes and networks. International conferences were held at: West Lafayette, Indiana, U.S.A. (1963); Yakutsk, Siberia (1973); Edmonton, Canada (1978); Fairbanks, Alaska (1983); Trondheim, Norway (1988); Beijing, China (1993); Yellowknife, Canada (1998); and Zurich, Switzerland (2003). The Ninth International Conference on Permafrost (NICOP) will be in Fairbanks, Alaska, June 29-July 3, 2008. Field excursions are an integral part of each Conference, and are organised by the host country. Regional conferences are organised between the main conferences (Europe, Russia, China).

\section{Organization and Structure}

Membership is through adhering national or multinational organisations or as Associate Members in countries where no Adhering Body exists. The IPA is governed by an Executive Committee and a Council consisting of representatives from 26 Adhering Bodies and Associate Members having interests in some aspect of theoretical, basic and applied frozen ground research, including permafrost, periglacial phenomena, seasonal frost, and artificial ground freezing.

The officers of the six-member Executive Committee (2003-2008) are:

President: Dr. Jerry Brown (U.S.A.)

Vice Presidents: Professor Charles Harris (U.K.) and

Dr. Georgy Z. Perlshtein (Russia)

Members: Dr. Hans-W. Hubberten (Germany), Mr.

Don W. Hayley (Canada), and Professor Zhu Yuanlin (China).

The International Secretariat is based at the University Centre in Svalbard (UNIS) under the direction of Dr. Hanne H. Christiansen (Norway).

The IPA Constitution provides for three categories of Working Parties: standing committees (long-term), working groups (5-10 years) and task forces (2-3 years) that organise and coordinate research activities and special projects.

The first category includes a Standing Committee for Data, Information and Communication and an International Advisory Committee for the International Per- mafrost Conferences. There are ten Working Groups, each with two co-chairs and some with subgroups. These are:

- Antarctic Permafrost and Periglacial Environments

- Coastal and Offshore Permafrost

- Cryosol

- Glacier and Permafrost Hazards in High Mountains

- Isotopes and Geochemistry of Permafrost

- Mapping and Modelling of Mountain Permafrost

- Periglacial Landforms, Processes, and Climate

- Permafrost and Climate

- Permafrost Astrobiology

- Permafrost Engineering

Details of the Working Parties goals and activities are found on the IPA web site that is maintained at the University of Oslo in the Institute of Geosciences <http://www.geo.uio.no/IPA/>

Starting in 2005, the IPA Secretariat in UNIS is receiving support from the Norwegian Research Council to provide administrative support for IPA activities including preparation and distribution of Frozen Ground. Annual membership contributions are used for printing Frozen Ground, Working Parties and committee activities and representation at international meetings.

\section{Publications and Information}

Proceedings of peer-reviewed papers are produced for each International Permafrost Conference by the host country, as are field trip guidebooks. A list of publications is found on the IPA web site.

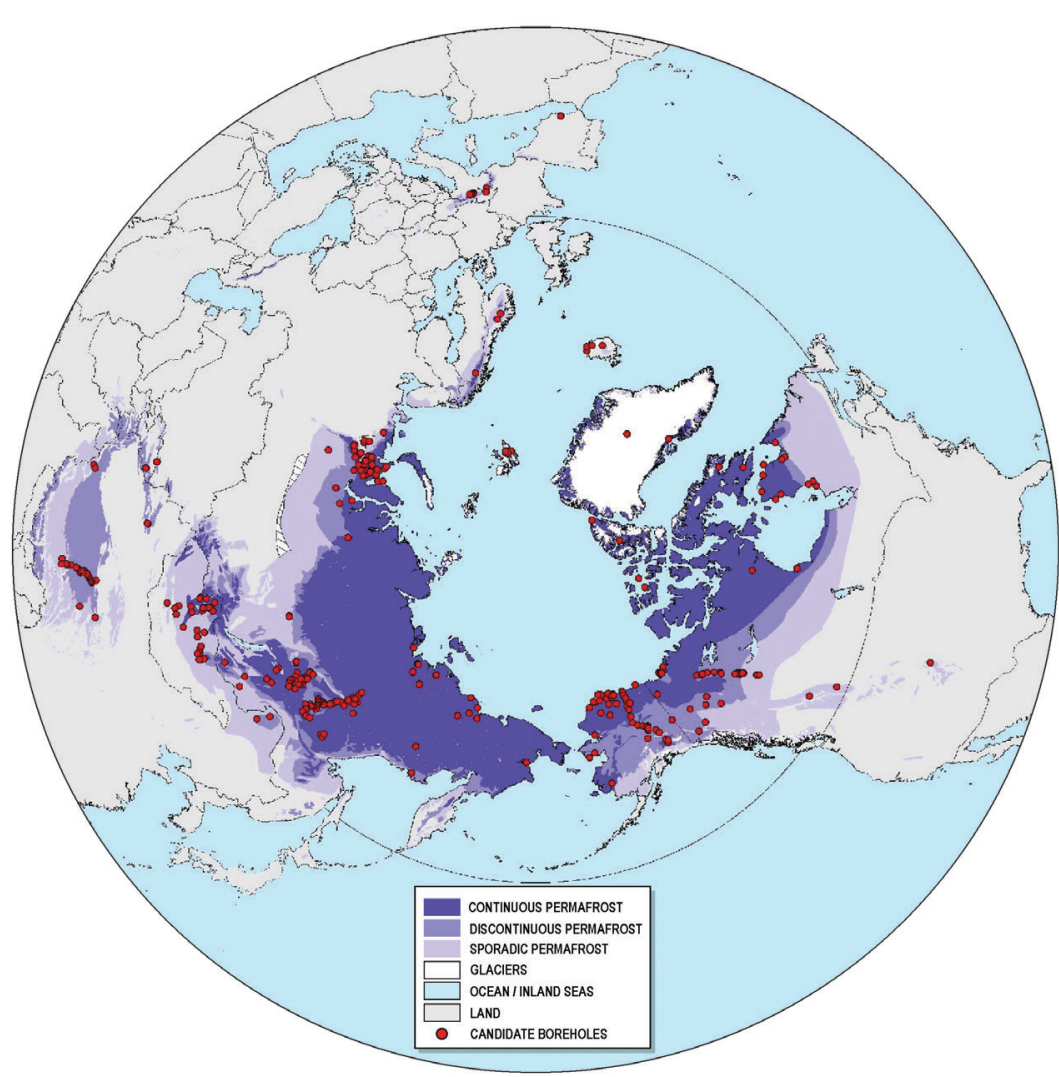

Figure 1 Northern Hemisphere map showing distribution of permafrost regions and location of boreholes currently in the GTN-P database. 
The News Bulletin Frozen Ground is published annually and has a distribution of over 2500. Current and back issues are posted on the IPA web site with many linkages to other activities.

The Circum-Arctic Map of Permafrost and Ground-Ice Condition at a scale of 1:10,000,000 (Figure 1) was prepared by an international team and published in the Circum-Pacific map series in 1997. Digital versions are available at several data centres. $<$ http://nsidc.org/fgdc>

The CAPS: Circumpolar Active-Layer Permafrost System, version 2.0 CD-ROM is a compilation of global frozen ground data and information. Permafrost: A Bibliography (1988-2003) Glaciological Data Report GD-31 is an online bibliography of the world's literature. Both are produced in conjunction with the International Permafrost Conferences and available from the National Snow and Ice Data Center.

An illustrated Glossary of Permafrost and Related Ground-Ice Terms in 12 languages (Chinese, English, French, German, Icelandic, Italian, Norwegian, Polish, Romanian, Russian, Swedish, and Spanish), 278 pages, was produced in 1998 and available online.

IPA cooperates with the American Geological Institute by providing literature to its Cold Regions Bibliography Project.

\section{Major Activities}

The IPA coordinates and cooperates with several other major international programmes and organisations. Briefly these are:

Global Terrestrial Network for Permafrost (GTN-P) is a WMO network for monitoring of the active layer and the thermal state of permafrost (TSP). The IPA manages the GTN-P (www.gtnp.org). The Circumpolar Active Layer Monitoring (CALM) program has 125 reporting stations and TSP has identified over 425 boreholes; both include a total of over 15 participating countries.

Arctic Coastal Dynamics (ACD) is a joint programme with the International Arctic Science Committee (IASC) and the IGBP LOICZ programme to estimate the organic carbon content and mineral transfer for eroding permafrost onto the Arctic shelves. We are collaborating with the International Quaternary Association (INQUA).

The IPA has a Memorandum of Understanding with the Climate and Cryosphere (CliC) programme of the World Climate Research Programme (WCRP). The main areas of cooperation are on the roles of permafrost on water and carbon balances, and data assimilation and modelling.

Beginning in 1995 the IPA and the International Geographical Union (IGU) developed an Agreement of Cooperation, thus making IPA an affiliate of the IGU. The current IGU collaboration is with its Commission on Cold Region Environments.

Coordination of activities on permafrost, soils and periglacial environments of the Antarctic and sub-Antarctic islands is a joint programme with an Expert Group of the Scientific Committee for Antarctic Research (SCAR).

Activities related to glacier and permafrost hazards in the high mountains (GAPHAZ) are a joint activity with the IUGG and its newly designated Commission for the Cryospheric Sciences.

The topic of carbon sources and sinks in cold regions soils (cryosols) and permafrost is a joint programme with the Global Carbon Project (GCP) and the joint working group on Cryosol of the IUSS.

\section{Recent and Future Activities}

IPA is planning to commemorate the 125th anniversary of the International Polar Year by participating in the 2007-2009 IPY with three coordinated projects. The Thermal State of Permafrost (TSP) proposes to obtain a "snapshot" of permafrost temperatures throughout Planet Earth during the period 2007-2008. Some of the boreholes to be measured are shown on the map. Another objective of TSP is to establish a permanent International Network of Permafrost Observatories (INPO) within the framework of the GTN-P. The two other IPY projects are concerned with Antarctic soils, permafrost, and periglacial processes and Arctic circumarctic coastal processes and local communities. Other IPY-related activities include a revised inventory of the quantity of carbon in permafrost regions, and revised regional permafrost maps of Central Asia and the Nordic region.

Several regional permafrost and soils conferences were held and are planned: The Second European Conference on Permafrost in Potsdam, Germany was held in June 2005; the Fourth International Conference on Cryopedology, was held Arkhangelsk in August 2005; and an Asian Conference on Permafrost will be convened in Lanzhou, China in early August 2006 with a field excursion to the Qinghai-Tibet Plateau <www.casnw.net/permafrost/home.html>. Planning for the Ninth International Permafrost Conference in early summer 2008 in Fairbanks is underway (www.nicop.org ). IUGS members are invited to these regional conferences and the NICOP.

\section{Relationship to IUGS}

As an Affiliated Organization, IPA encourages its Working Groups to develop partnerships with organizations with common interests. We are working with the Geoindicator Initiative (GEOIN) and have begun to collaborate with the Commission on Management and Application of Geoscience Information (CGI). We plan to participate in the International Year of Planet Earth and the themes related to climate, hazards, and soils. IPA proposes to work closely with the organisers of the $33^{\text {rd }}$ International Geological Congress that focuses on the Arctic so that appropriate results of the NICOP are conveyed to the Congress participants with special publications and sessions. Also included is participation in Congress field excursions throughout the Nordic countries to illustrate the diverse permafrost and periglacial environments of the North Atlantic region.

\author{
Dr. Jerry Brown \\ President \\ International Permafrost Association \\ P.O.Box 7 \\ Woods Hole, MA 02543 \\ USA \\ E-mail: jerrybrown@igc.org \\ Tel/Fax: 15084574982
}

\section{Dr. Hanne H. Christiansen}

International Permafrost Association Secretariat

The University Centre in Svalbard (UNIS)

P.O.Box 156

9171 Longyearbyen

NORWAY

E-mail:IPA@unis.no

Tel: 4479023300

Fax: 4779023301 